\title{
Influence of Social Skills and Stressors on Academic Achievement in the Sixth-Grade ${ }^{1}$
}

\author{
Neidiany Vieira Jovarini², Vanessa Barbosa Romera Leme ${ }^{3}$, \\ Marta Regina Gonçalves Correia-Zanini ${ }^{4}$ \\ ${ }^{2}$ Universidade Salgado de Oliveira, Niterói-RJ, Brazil \\ ${ }^{3}$ Universidade do Estado do Rio de Janeiro, Rio de Janeiro-RJ, Brazil \\ ${ }^{4}$ Centro Universitário das Faculdades Associadas de Ensino, São João da Boa Vista-SP, Brazil
}

\begin{abstract}
Transition to middle school (MS) expressions changes in interpersonal relations and academic demands that can influence the academic achievement of students. This study aimed to evaluate the influence of social skills and perception of school stressors of students as predictors of academic achievement in the transition to the 6th grade of the MS. 214 students (aged 11 to 17 years) participated, of both genders of the 6th grade, of the state of Amazonas. Students answered the Social Skills Inventory for Adolescent and the Inventory of School Stressors. The predictive model indicated that the social skills of assertiveness, empathy and emotional approach and school stressors related to stress related to the student's role predicted $18 \%$ of the academic achievement. The survey data can be used in future interventions with students, their families and teachers.
\end{abstract}

Keywords: social skills, academic achievement, elementary education

\section{Influência das Habilidades Sociais e Estressores sobre o Desempenho Escolar no $6^{\circ}$ ano}

\begin{abstract}
Resumo: A transição para os anos finais do Ensino Fundamental (EF) apresenta mudanças nas relações interpessoais e nas demandas acadêmicas que podem influenciar o desempenho escolar dos estudantes. Este estudo teve por objetivo avaliar as influências das habilidades sociais e da percepção de estressores escolares dos alunos como variáveis preditoras do desempenho escolar na transição ao $6^{\circ}$ ano do EF. Participaram 214 alunos (idade entre 11 e 17 anos), de ambos os sexos do $6^{\circ}$ ano da rede estadual do Amazonas. Os estudantes responderam ao Inventário de Habilidades Sociais para Adolescentes e ao Inventário de Estressores Escolares. O modelo preditivo evidencia que as habilidades sociais de assertividade, empatia e abordagem afetiva e os estressores escolares referentes à tensão relacionada ao papel do estudante predisseram $18 \%$ do desempenho escolar. Os dados da pesquisa poderão ser utilizados em futuras intervenções com os alunos, suas famílias e professores.
\end{abstract}

Palavras-chave: habilidades sociais, rendimento escolar, ensino fundamental

\section{Influencia de las Habilidades Sociales y Factores de Estrés sobre lo Rendimiento Escolar el $6^{0}$ año}

\begin{abstract}
Resumen: La transición al final de años de la educación primaria (E.P.) evidencia los cambios en las relaciones interpersonales y las exigencias académicas que pueden influir en el rendimiento escolar de los estudiantes. Este estudio tuvo como objetivo evaluar la influencia de las habilidades sociales y la percepción de los factores de estrés de la escuela de los estudiantes como predictores del rendimiento escolar en la transición hacia el $6^{\circ}$ año de E.P. Participaron 214 alumnos (de entre 11 a 17 años) de ambos sexos del 6 año de la red estatal del Amazonas. Los estudiantes respondieron el Inventario de Habilidades Sociales para Adolescentes y el Inventario de la Factores de Estrés de la Escuela. El modelo predictivo evidencia que las habilidades sociales de la asertividad, empatía y enfoque emocional y los estresores escolares referentes a la tensión relacionada al papel del estudiante predijeron $18 \%$ del desempeño escolar. Los datos de la encuesta serán utilizados en futuras intervenciones con los estudiantes, sus familias y profesores.
\end{abstract}

Palabras clave: habilidades sociales, rendimiento escolar, enseñanza de primer grado

\footnotetext{
${ }^{1}$ Paper derived from the master's dissertation of the first author under the supervision of the second, defended in 2015, in the Graduate Program in Social Psychology of the Universidade Salgado de Oliveira.
}

Correspondence address: Vanessa Barbosa Romera Leme. Universidade do Estado do Rio de Janeiro. Instituto de Psicologia. Rua São Francisco Xavier, Maracanã, $10^{\circ}$ andar, Bloco D, Sala 10.006, Rio de Janeiro-RJ, Brazil. CEP 20.550-900. E-mail: vanessaromera@gmail.com 
The Bioecological Theory of Human Development (BTHD) highlights the importance of person resources and family, school and community contexts for healthy development in early adolescence (Bronfenbrenner \& Morris, 1998; Eccles \& Roeser, 2011). In this context some studies have focused on the relationships that occur in the school as promoters of the positive development of adolescents (Kim, Schwartz, Cappella, \& Seidman, 2014). In the bioecological conception, the students' entry into the 6th grade of MS can be understood as an ecological transition, that is, when a change of role, environment or both occurs (Bronfenbrenner \& Morris, 1998). It is a period of unpredictability that can generate stress and anxiety for students, harming academic performance (Marturano, 2008).

Throughout the school trajectory, the adolescents experience several transitions that involve since the change of schools as well as the change of school cycles that can interfere in their social-emotional development and academic performance (Eccles \& Roeser, 2011; Lane, Oakes, Carter, \& Messenger, 2015). In Brazil, the socalled Middle School is currently divided into Initial Years, which comprise 1st to 5th grade (equivalent to Elementary School), and Final Years, which comprise the 6th to 9th grades (equivalent to Middle School). The admission in the 1st grade (Cadima, McWilliam, \& Leal, 2010), as well as in 6th grade are two important transitions experienced by students in MS (Dawes \& Xie, 2016; Lane et al., 2015). However, despite growing publications about the transition to the 1st grade, little attention has been given to the transitions occurring within the same school segment, as is the case of the passage from the 5th to the 6th grade (Lane et al., 2015).

In the national context, studies have evidenced the importance of investigating children's resources (for example, social skills) and their contexts (positive educational practices) to facilitate interpersonal and academic adaptation in the transition to the 1st grade of Elementary Education (Bolsoni-Silva \& Mariano, 2014; Correia-Zanini \& Marturano, 2015; Leme \& Marturano, 2014; Marturano, Trivellato-Ferreira, \& Gardinal, 200; Stasiak \& Weber, 2013). But it seems obvious that the 6th grade of the MS, like the 1st grade, demands adaptation by the students to the various structural, academic and relational changes (Dawes \& Xie, 2016; Lane et al., 2015; Sebanc, Guimond, \& Lutgen, 2016). However, with its own characteristics, for example, it is no longer necessary to have a centralized structure in a single teacher for each class for a system with several teachers that take turns in classes, as well as the existence of a larger number of school subjects and more numerous classrooms (Shoshani \& Slone, 2012). These changes may make the student-teacher relationship less close, making it difficult to form a bond between them, which may decrease students' motivation and lead to difficulties in the teachinglearning process (Kim et al., 2014).

At the same time that the relationship between students and teachers becomes more distant, the academic requirements are intensified. Teachers are expected to have greater autonomy and responsibility for curriculum content (Lane et al., 2015). This new configuration of the school environment makes the transition to 6th grade a more propitious period for the perception of stressful school events (Eccles \& Roeser, 2011). In addition to this, students are in their early teens and need to deal with biological and psychosocial changes that make this phase of the life cycle more prone to the onset of psychopathological disorders and behavioral problems (Eccles \& Roeser, 2011; Moilanen, Shaw, \& Maxwell, 2010). These factors together make the school a potential external source of stress (Byrne, Thomas, Burchell, Olive, \& Mirabito, 2011).

For Marturano et al. (2009) based on Elias (1989), there are four adaptive tasks resulting from the school transition: (a) adjusting to changes in the student role, (b) to be in the extended social network, (c) to conform to the norms and rules of the new context and (d) to deal with the stress associated with the unpredictability and uncertainties as a result of this transition. When the demands resulting from these tasks exceed the resources that the child presents, stress can be triggered. The authors also point out that children are more vulnerable to daily stressors because they lack cognitive resources, coping strategies and because they have less control over events than adults.

In the context of the transition to the 1st grade, there may be daily hassles or school stressors that are understood as the experiences that the students evaluate as harmful or threatening to their well-being (Correia-Zanini \& Marturano, 2015; Marturano et al., 2009). In this direction, Brazilian researchers found that the perception of stress in the transition to the 1st grade or during the Initial Years of MS correlated negatively both aspects of interpersonal development and academic achievement of students (Correia-Zanini, 2013; Marturano et al., 2009). Some international studies have identified negative associations between perceptions of stress and academic achievement in the transition to the 6th grade of MS (Erath, Bub, \& Tu, 2016; Lane et al., 2015). The study by Erath et al. (2016) indicated that the perception of school stressors, mainly related to relations among peers, was a negative predictor of the academic achievement of 6th grade students. Similarly, Lane et al. (2015) found that in the transition to 6th grade adolescents face a number of challenges such as peer acceptance/rejection, bullying episodes, and new love experiences that have been associated with increased stress perception and lower levels of academic achievement. On the other hand, the daily stresses of the school environment can be managed by students with more or less success, depending both on the social support of parents and teachers and their interpersonal skills (Correia-Zanini \& Marturano, 2015).

The transition to the 6th grade can be considered a critical moment in schooling to the extent that pre-existing problems may arise or new difficulties arise (Symonds \& Hargreaves, 2016). In the present study, the students' behavioral and academic problems in childhood may remain in adolescence when students and their parents 
present deficits in social skills (Berry \& O'Connor, 2010; Moilanen et al., 2010).

According to Z. A. P. Del Prette e A. Del Prette (2010), social skills refer to the diverse set of behaviors of a person's repertoire that can contribute to its social competence, leading to healthy and productive relationships. In adolescence, offering support, apologizing, initiating and maintaining conversation, refusing requests without harming the relationship, establishing a loving relationship, among others, are some of the social skills required in the new interpersonal and academic tasks presented to adolescents (A. Del Prette \& Z. A. P. Del Prette, 2009). These social skills can help students in times of school transition, in the resolution of interpersonal conflicts, in the confrontation of adversities, minimizing stress and promoting their adaptation to new academic demands (Correia-Zanini \& Marturano, 2015).

Studies suggest that students with few social skills have greater difficulty in socializing with colleagues and teachers, and may present behavioral difficulties and experience academic failure (Gresham, Elliot, \& Kettler, 2010). Social skills function as a predictor of academic achievement (Feitosa, Z. A. P. Del Prette, \& A. Del Prette, 2012; Marturano \& Pizato, 2015; Romano, Babchishin, Pagani, \& Kohen, 2010), being positively correlated with the good academic performance in the transition to the 6th (Chen, Huang, Chang, Wang, \& Li, 2010; Maia \& Soares, 2014) and, in general, in the Final Years of the MS (Cia \& Costa, 2012; Feitosa et al., 2012; Konold, Jamison, StantonChapman, \& Rimm-Kaufman, 2010; Romano et al., 2010).

The findings of these studies corroborate the hypothesis that the transition from the Initial Years to the Final Years of MS is a moment of the school trajectory that can lead to a decline in academic achievement and social skills. However, these findings do not give indicative if these results are maintained in subsequent years (Moilanen et al., 2010). Anyway, if during childhood it was not possible to prevent and / or change unfavorable developmental trajectories, early adolescence would be an opportune moment to promote social and academic competencies (Berry \& O'Connor, 2010).

The literature review indicated that most of the research has prioritized the MS Initial Years (Bolsoni-Silva \& Mariano, 2014; Cadima et al., 2010; Correia-Zanini, 2013; Correia-Zanini \& Marturano, 2015; Leme \& Marturano, 2014; Marturano et al., 2009; Marturano \& Pizato, 2015; Stasiak \& Weber, 2013), with little emphasis on the transition to the MS Final Years. Among these, only Correia-Zanini (2013) and Marturano and Pizato (2015) jointly evaluated the variables school stress, social skills and academic achievement. Correia-Zanini found positive correlations between social skills and academic performance, with students from the 1 st to 3 rd grade of the MS, and negative correlations between the perception of school stressors and academic competence. Marturano and Pizato (2015) verified the social skills assessed with students in the 3rd grade of MS, and positively predicted academic competence in the 5 th grade, while the perception of stress related to the role of school student was a negative predictor. Only a Brazilian research (Maia \& Soares, 2014) investigated the transition to the 6th grade of MS, with the objective of analyzing associations between social skills, behavior problems and academic competence, evidencing an area open to research. The results of this study indicated positive correlations between the social skills and the academic competence of the students (Maia \& Soares, 2014).

Data from the National Institute of Educational Studies and Research Anísio Teixeira (acronym in Portuguese: Inep), from 2015, indicate that many students do not finish the MS, and the dropout rate in the 6th grade of MS in public schools in Brazil was 4.4\%; while in the city of Humaitá-AM, where data was collected, it was $7.1 \%$. Therefore, this specific year of schooling is a crucial period for investigating both risk and protective factors that may be used in intervention programs with learners to improve their academic achievement. Thus, the present study aimed to evaluate the influences of social skills and the perception of students' school stressors as predictor variables of academic achievement in the transition to the 6th grade of Middle School.

\section{Method}

\section{Participants}

A total of 214 students $(M=11.82, S D=1.14)$, of both genders (103 girls and 111 boys) attending the 6th grade of MS of three state public schools in the State of Amazonas participated. As regards the socioeconomic level of the students' families, $37.85 \%$ belonged to class $\mathrm{C} 2,25.7 \%$ to class $\mathrm{D}, 24.76 \%$ to class $\mathrm{C} 1,10.28 \%$ to class $\mathrm{B} 2,0.93 \%$ to class B1.

\section{Instruments}

Social Skills Inventory for Adolescent - SSIA-Del-Prette. Developed by A. Del Prette and Z. A. P. Del Prette (2009) to evaluate the social skills of adolescents from their self-reports on daily situations. It presents 38 items that contemplate different social skills divided into six factors: Empathy - "When you notice that a classmate is sad or with some difficulty in school, you offers support or help"; Self-control - "When criticized by parents and teachers you can calm down and control irritation"; Civility - "When someone does something good you can praise and thank him/her when they receive praise"; Assertiveness "If you feel wrong to do something, even colleagues pressured you, you do not do what your colleagues want"; Affective Approach - "When you want to make friends, you invite the person to some program or activity"; Social Development "At school you can make group oral presentations when requested". Responses are arranged on a five-point Likert scale ranging from 0 (never) to 4 (always). A. Del Prette and Z. A. P. Del Prette (2009) administered the instrument to 1172 adolescents of both genders and found satisfactory indexes of internal consistency $(\alpha=0.89$ for the total scale and 0.68 to 
0.85 for the factors). Z. A. P. Del Prette, Teodoro and A. Del Prette (2014) showed convergent validity (from $r=0.29$ to $r=$ 0.59 ) between some factors of the SSIA and the social skills/ assertiveness factors of the Matson Evaluation of Social Skills with Youngsters. In the present study, the following reliability indexes were found (Empathy $\alpha=0.81$; Self-control $\alpha=0.77$; Civility $\alpha=0.83$; Assertiveness $\alpha=0.71$; Affective Approach $\alpha=0.61$; Social Development $\alpha=0.57$; instrument total $\alpha=$ $0.91)$.

Inventory of School Stressors - ISS. It is an instrument that was developed by Trivellato-Ferreira and Marturano (2008), based on an interview conducted by Rende (1994) that aims to verify the perception of school stressors in the school environment. Afterwards, the instrument was evaluated by Correia-Zanini (2013) with a sample of 186 students of the 1st grade, 171 students of the 2 nd grade and 151 students of the 3 rd grade, aged 5 to 8 years. The final version used in the present study refers to the structure found in Correia-Zanini from the Factorial Confirmatory Analysis, with students of the 3rd grade, consisting of 17 items composed of two factors: F1 - Hassles related to student role with 10 items ("I took low notes", $\alpha=0.69$ ); e F2 - and F2 - Interpersonal relationships with 7 items ("My classmates beat me", $\alpha=0.71$ ). For each situation presented, the child responds if that happened during the school year (no or yes), if it happened, it also informs how much the situation upset him/her, which is presented in a scale Likertde 1 (nothing) to 4 (much). For the present sample, the following reliability indexes were found: FI $\alpha$ $=0.60, \mathrm{~F} 2 \alpha=0.45$ and total ISS $\alpha=0.74$.

Demographic information and socioeconomic level questionnaire. It is an instrument developed for this study to investigate the social and demographic characteristics of the participants, such as age, gender and color. The Brazilian Economic Research Questionnaire (ABEP, 2013) which evaluates the socioeconomic level and allows the stratification of families, in descending order of purchasing power, into five classes: A (A1 and A2), B (B1 and B2), C, $\mathrm{D}$ and $\mathrm{E}$.

\section{Procedure}

Data collection. After the delivery of the Free and Informed Consent Form (FICF), which was signed by the legal guardians of the students and with the consent of the students, data collection was done collectively in the classrooms, at the times that were previously agreed with the teachers. At the beginning of each application (average duration of 50 minutes) was presented to the students the research objective, the guarantee of confidentiality of the data collected and reiterated the voluntary nature of their participation.

Data analysis. A correlational and predictive study was performed with a sample selected for convenience. Data analysis was performed using the software Statistical Package for the Social Sciences for Windows (SPSS, version 22.0). First, the correlation between the study variables (Pearson's coefficient $r$ ) was calculated. Subsequently, the assumptions of normality, independence and multicollinearity were tested and confirmed, and then multiple linear regression analysis (stepwise method) was performed. Academic achievement was the dependent variable and refers to the final average (ranges from 0.0 to 10.0), obtained by the sum of the grades of all the disciplines computed in the Final Results Minutes of the first semester of the year in which the collection was performed. The six factors of the SSIA-Del-Prette (empathy, self-control, civility, assertiveness, affective approach and social development), and the two factors of the ISS (hassles related to student role and interpersonal relations).

\section{Ethical Considerations}

The project, in accordance with Resolution 466/12 of the National Health Council, was approved, in accordance with Process No. 883.882 - CAAE: 37974914.5.0000.5289 by the Research Ethics Committee of the University where the study was carried out.

\section{Results}

Table 1 presents the correlations between social skills, school stressors and academic achievement. The results indicate negative correlations of the social skill affective approach and of hassles related to the student role with the students' and academic achievement. The social skills of assertiveness and empathy are positively associated with students' and academic achievement.

Table 2 presents the predictive variables for the students' academic achievement. The significant model $(F(4.20)=13.03, p=0.01)$ indicates that the hassles related to student role and social skills assertiveness, affective approach and empathy explain $18 \%$ of the variability of students' academic achievement. The results show that the hassles factor related to the role of students had greater weight on academic achievement. 
Table 1

Correlations between the Social Skills Variables, School Stressors and Academic Achievement of the 6th grade of Middle School

\begin{tabular}{|c|c|c|c|c|c|c|c|c|c|}
\hline Variables & 1 & 2 & 3 & 4 & 5 & 6 & 7 & 8 & 9 \\
\hline SS1 -Empathy & 1 & & & & & & & & \\
\hline SS1 - Self-control & $-0.37^{* *}$ & 1 & & & & & & & \\
\hline SS1 - Civility & $0.45^{* *}$ & $0.30^{* *}$ & 1 & & & & & & \\
\hline SS1 - Assertiveness & $0.32^{* *}$ & $0.32^{* *}$ & $0.36^{* *}$ & 1 & & & & & \\
\hline SS1 -Affective Approach & $0.54^{* *}$ & $0.26^{* *}$ & $0.37^{* *}$ & $0.14^{*}$ & 1 & & & & \\
\hline SS1 - Social Development & $0.62^{* *}$ & $0.39^{* *}$ & $0.40^{* *}$ & $0.41^{* *}$ & $0.44^{* *}$ & 1 & & & \\
\hline SS2 - Hassles related to student's role & -0.10 & -0.11 & -0.01 & -0.12 & 0.04 & -0.03 & 1 & & \\
\hline SS2 - Interpersonal Relations & 0.01 & 0.02 & -0.01 & 0.04 & 0.04 & 0.02 & $0.29^{* *}$ & 1 & \\
\hline Academic Achievement & $0.12 *$ & 0.11 & 0.07 & $0.19^{* *}$ & $-0.14^{*}$ & 0.01 & $-.035^{* *}$ & -0.03 & 1 \\
\hline
\end{tabular}

Note. $N=214 . \mathrm{SS} 1=$ Social Skills; $\mathrm{SS} 2=$ School Stressors; ${ }^{*} p<0.05 ; * * p 0.01$.

Table 2

Regression Model for the Prediction of Academic Achievement of Students in the 6th Grade of Middle School

\begin{tabular}{|c|c|c|c|c|c|c|}
\hline Predictors & Const. & $\begin{array}{c}B \\
(\mathrm{EP} B) \\
\end{array}$ & $\beta$ & $95 \%$ IC & $R^{2}$ & $\begin{array}{c}\text { Tolerance } \\
(V I F)\end{array}$ \\
\hline SS2 - Hassles related to the student's role & $8.02 * *$ & $-0.05(0.01)$ & -0.31 & {$[-0.07,-0.03]$} & $0.12 * *$ & $\begin{array}{c}0.96 \\
(1.03)\end{array}$ \\
\hline SS1 - Assertiveness & $7.71 * *$ & $0.20(0.01)$ & 0.12 & {$[0.01,0.04]$} & $0.14 * *$ & $\begin{array}{c}0.88 \\
(1.33)\end{array}$ \\
\hline SS1 - Affective Approach & $7.94 * *$ & $-0.04(0.01)$ & -0.26 & {$[-0.07,-0.02]$} & $0.16^{* *}$ & $\begin{array}{c}0.69 \\
(1.44)\end{array}$ \\
\hline SS1 - Empathy & $7.67 * *$ & $0.02(0.01)$ & 0.19 & {$[0.01,0.04]$} & $0.18 * *$ & $\begin{array}{c}0.63 \\
(1.58)\end{array}$ \\
\hline
\end{tabular}

Note. $N=214 ; B=$ non standardized regression coefficient, EP $B=$ Standard error of the non-standardized regression coefficient; $\beta=$ standardized regression coefficient; $\mathrm{CI}=$ Confidence Interval; $R^{2}=$ adjusted coefficient of determination; VIF = Variance Inflation Factor; $\mathrm{SS} 2=$ School Stressors; SS1 $=$ Social Skills; $* p<0.05 ; * *<0.01$.

\section{Discussion}

The transition to the 6 th grade of the MS is a moment of school trajectory that can lead to the emergence of interpersonal and academic difficulties (Eccles \& Roeser, 2011; Marturano, 2008). Based on these premises, this study aimed to evaluate the influence of social skills and the perception of school stressors on the academic achievement of students who attend the 6 th grade of the MS. The literature indicates that due to the changes in curricular structure and new social demands that characterize the transition to 6th grade of MS, students may present more stress (Lane et al., 2015) and less social skills (Chen et al. 2010; Maia \& Soares, 2014), leading to lower levels of academic achievement. Corroborating these findings and other research with students in the Initial Years (Correia-Zanini, 2013; Marturano et al., 2009) and Final Years of MS. (Cia \& Costa, 2012; Konold et al., 2010; Romano et al., 2010), the results in the present study (Table 1) have shown, in some degree, that the social skills of empathy and assertiveness have positively correlated with academic achievement, while school stressors related to the student's role were negatively associated with academic achievement.

The regression model tested (Table 2) showed that the perception of school stressors related to hassles as a student role was the variable with the greatest explanatory power in the students' academic achievement in the transition to the 6th grade of MS. In this way, it can be understood that the more the student perceives the hassles related to the student role present in his/her school context, such as dealing with low grades, finishing classroom lessons and needing help to do the activities requested by the teacher, the lower his/her academic achievement, responding to the results of CorreiaZanini (2013) and Marturano and Pizato (2015).

However, unlike the findings found in this study, other studies (Marturano et al., 2009; Stasiak \& Weber, 2013) identified that the greatest source of school stressors perceived by students was related to interpersonal relationships, especially in relation to peers. These differences may be due to the fact that such researches focused on the transition to the 
1st grade of MS. Thus, it may be assumed that the demands faced by students at the beginning of SM require more skills related to the formation of new links with peers, whereas in the transition in the 6th grade, while in the transition to the 6th grade the charges related to academic achievement are more prominent, generating more students' perception of stress for academic issues (Marturano \& Pizato, 2015).

However, Correia-Zanini (2013) verified that in the first year the students perceived more the school stressors related to the hassles of the student's role and less in relation to the interpersonal relationship. Although during the Initial Years of the 1st cycle of the MS, the perception of school stressors related to the hassles of the student's role diminished and slightly increased the perception of school stressors regarding the interpersonal relationship, which is in accordance with the study of Erath et al. (2016). These discrepant results indicate that the perception of school stressors needs to be more investigated in the Brazilian context.

In the transition to 6th grade, students need to adapt to an academic curriculum with a greater number of school subjects and tests, numerous classrooms, and a greater relay of teachers (Shoshani \& Slone, 2012). This new organization of school activities can make teachers perceive the students as more demanding and distant, contributing to difficulties in the student-teacher relationship (Kim et al., 2014; Lane et al., 2015) e and increasing the perception of stress. Therefore, school can become an external source of stress as is suggested in other researches (Byrne et al., 2011; Correia-Zanini \& Marturano, 2015; Erath et al., 2016; Marturano, 2008). Facing this context, it is important that both parents and teachers act as networks of socio-affective support for adolescents at this time in academic life (Lane et al., 2015). However, the Final Years of MS have been poorly focused in the Brazilian context compared to studies that focus on the transition to the 1st grade (Bolsoni-Silva \& Mariano, 2014; Cadima et al., 2010; Correia-Zanini \& Marturano, 2015; Leme \& Marturano, 2014; Marturano et al., 2009; Stasiak \& Weber, 2013), which also makes it difficult the discussion with previous data.

Among the six social skills tested, only assertiveness, empathy, and affective approach were predictors of students' academic achievement in the 6th grade of MS transition. Congruent with data from previous researches (Feitosa et al., 2012; Marturano \& Pizato, 2015; Romano et al., 2010), the results indicated the positive predictive effect of social skills of assertiveness and empathy associated positively with academic achievement. The social skill of assertiveness in adolescence consists of the manifestation of behaviors of expressing negative feelings (anger or dislike) agreeing or disagreeing with opinions, making and refusing requests, dealing with criticism and joking, asking for behavior change, negotiating conflicting interests, defending one's own rights and resisting peer pressure (A. Del Prette \& Z. A. P. Del Prette, 2009). The presentation of these behaviors is necessary for the emergence of healthy interpersonal relationships in adolescence, since adolescents are more susceptible to yielding to the negative pressure and influence of their peers, favoring the emergence of behavioral problems (Dawes \& Xie, 2016; Eccles \& Roeser, 2011).

The social skill of empathy consists in showing respect for differences, expressing understanding by the feeling or experience of the other, sharing, observing, paying attention, recognizing/inferring feelings of the interlocutor, understanding the situation (A. Del Prette \& Z. A. P. Del Prette, 2009). This skill contributes to the formation of new friendships and the maintenance of interpersonal relationships both with colleagues and with teachers. In this sense, Sebanc et al. (2016) found positive correlations between quality of the relationship with peers and academic achievement. According to the authors, the negative effects of transition to the 6th grade can be neutralized or reduced if students were able to maintain friendships or make new classmates when there was a change of school. In addition, empathy is also the behavior of offering help and sharing, which favors the accomplishment of the tasks and the group work, helping the academic achievement that, in the transition to the 6th grade of the MS, requires adaptation to several changes, among them, a school curriculum composed of several different subjects (Shoshani \& Slone, 2012).

Differently from what has been found (Maia \& Soares, 2014), the affective approach in this study was a significant predictor and was negatively associated with students' academic achievement. This social skill consists of behaviors directed to the peers, such as initiating and maintaining conversation to establish relationships of friendship, as well as those directed toward romantic partners, as expressing satisfaction and dissatisfaction about different forms of affection (A. Del Prette \& Z. A. P. Del Prette, 2009). Such skills are required in the new interpersonal tasks presented to adolescents, including dealing with increased family independence and initiating loving relationships that can foster positive interactions and well-being (Leme, Del Prette, \& Coimbra, 2015). However, such behaviors may be expressed by the students in the moments of paying attention to the teacher in the classroom, which may have hampered the student's learning process. Thus, considering the healthy influences of this social skill in adolescence, future studies need to further investigate this relationship insofar as it differs from the results found in other researches.

Research has recurrently signaled that students with poor academic achievement have fewer social skills in the Final Years of MS (Cia \& Costa, 2012; Feitosa et al., 2012; Konold et al., 2010; Romano et al., 2010) and, specifically, in the transition to the 6th grade (Chen et al., 2010; Maia $\&$ Soares, 2014). According to the literature, poor academic achievement is considered a risk factor for psychosocial problems (Berry \& O'Conner, 2010). In turn, such deficits in social skills can lead to behavioral, emotional and learning problems (Gresham et al., 2010). Students with low academic achievement present problems in their productive capacity, in the acceptance of their age peers and their relatives and in other areas of their development (Gresham et al., 2010).

Therefore, even though interpersonal and academic difficulties may increase (Simonds \& Hargreaves, 2016), but 
also stabilize or diminish with the end of MS (Moilanen et al., 2010), teachers and parents need to provide social support and use skills in the process of socializing students to avoid low academic achievement. Above all, it is necessary that the school carries out educational actions that contribute to the improvement of the psychological aspect of the students. In this way, the chances of improving the academic and interpersonal competence of the students and, consequently, their academic achievement are increased.

The research contributed to a research area that focuses on the Final Years of MS, demonstrating that stressors related to the student role and the social skills of assertiveness, empathy and affective approach, as a whole, explained $18 \%$ of the variability of the students' academic achievement in the transition to the 6th grade. Consistent with the bioecological conception (Bronfenbrenner \& Morris, 1998), the findings indicated that students' bioecological characteristics (social skills) and context variables (daily stress at school) influence academic achievement. These students may find it difficult to cope with new demands presented to them at this time of ecological transition, such as adapting to a greater number of disciplines and teachers, reducing the time spent with the same teacher, needing to make new friendships, school changes, in some cases, and possible learning difficulties and behavior, from the previous teaching stage.

The data found should be analyzed along with the limitations of the present study. Firstly, the cross-sectional design is used. A longitudinal study could be useful to evaluate how the changes in students' behavior would be in the Final Years of MS. Second, the school average was used, which is a non-standardized measure, obtained in schools to evaluate students' academic achievement. On the one hand, the use of the final average of the students allowed having a contextualized evaluation of the educational reality of the schools surveyed, but, on the other hand, it limits comparison with other sites. Thus, other performance measurement instruments could be used as the Brazil Test or the School Performance Test, or even measures of academic competence, such as the Social Skills Assessment System (SSAS), in the teachers' version. Third, the predictive model indicated that $18 \%$ of academic achievement variability was explained by predictor variables. This coefficient of determination is considered small, suggesting that other variables may influence academic achievement, and should be investigated in future studies. Fourth, it should be emphasized that the study was carried out in a small city (approximately 50 thousand inhabitants) and in only three schools of the state network of the municipality. Thus, it is important to note that the data should not be generalized, but contextualized according to the schools that the students were part of. Finally, the statistical analyzes do not allow definitive conclusions nor establish relations of cause and effect, but only correlational inferences.

Considering the limitations of the present study, it is suggested that later work could: (1) collect information with teachers about their educational social skills and working conditions; (2) to investigate other variables in the family and school contexts that may affect academic achievement, such as family environment resources, communication between parents and teachers, school climate and presence of bullying in schools, study rhythm, type of school, motivational variables of students, as well as self-efficacy and well-being; (3) propose preventive interventions and promote mental health with students, their families and teachers.

\section{References}

Associação Brasileira de Empresas de Pesquisa - ABEP. (2013). Critério de Classificação Econômica Brasil [Brazilian Economic Classification Criteria]. Retrieved from http://www.abep.org/criterio-brasil

Berry, D., \& O'Connor, E. (2010). Behavioral risk, teacherchild relationships, and social skill development across middle childhood: A child-by-environment analysis of change. Journal of Applied Developmental Psychology, 31(1), 1-14. doi:10.1016/j.appdev.2009.05.001

Bolsoni-Silva, A. T., \& Mariano, M. L. (2014). Práticas educativas de professores e comportamentos infantis, na transição ao primeiro ano do ensino fundamental [Educative practices of teachers and child behavior, the transition to the first year of elementary school]. Estudos e Pesquisas em Psicologia, 14(3), 814-833. doi:10.12957/ epp.2014.13912

Bronfenbrenner, U., \& Morris, P. (1998). The ecology of developmental processes. In W. Damon \& R. M. Lerner (Eds.), Handbook of child psychology: Vol. 1. Theoretical models of human development (5th ed., pp. 993-1027). New York, NY: John Wiley \& Sons.

Byrne, D. G., Thomas, K. A., Burchell, J. L., Olive, L. S., \& Mirabito, N. S. (2011). Stressor experience in primary school-aged children: Development of a scale to assess profiles of exposure and effects on psychological wellbeing. International Journal of Stress Management, 18(1), 88-111. doi:10.1037/a0021577

Cadima, J., McWilliam, R.A., \& Leal, T. (2010). Environmental risk factors and children's literacy skills during the transition elementary school. International Journal of Behavioral Development, 34(1), 24-33. doi: $10.1177 / 0165025409345045$

Cia, F., \& Costa, C. S. L. (2012). Desempenho acadêmico nas séries do ensino fundamental: Relação com o desenvolvimento social [Academic performance in basic education series: Relationship to social development]. Psicologia Argumento, 30(68), 109-118. Retrieved from http://www2.pucpr.br/reol/pb/index.php/ pa?dd $1=5889 \& d d 99=$ view $\&$ dd $98=$ pb

Chen, X., Huang, X., Chang, L., Wang, L., \& Li, D. (2010). Aggression, social competence and academic achievement in Chinese children: A 5-year longitudinal study. Development and Psychopathology, 22(3), 583592.doi:10.1017/S0954579410000295 
Correia-Zanini, M. R. G. (2013). Um estudo prospectivo sobre o percurso escolar de crianças nos primeiros anos do ensino fundamental [A prospective study of children's scholastic course in the first three years of Basic Education] (Doctoral dissertation). Retrieved from http://www.teses.usp.br/teses/disponiveis/59/59137/tde06012014-100239/pt-br.php

Correia-Zanini, M. R. G., \& Marturano, E. M. (2015). Sintomas de estresse em alunos do $1^{\circ}$ ano do Ensino Fundamental [Stress symptoms in students attending first grade]. Revista SPAGESP, 16 (1), 28-42. Retrieved from http://pepsic.bvsalud.org/scielo.php?script=sci_ arttext\&pid=S1677-29702015000100004

Dawes, M., \& Xie, H. (2016). The trajectory of popularity goal during the transition to middle school. Journal of Early Adolescence, 37(6), 852-883. doi:10.1177/0272431615626301

Del Prette, A., \& Del Prette, Z. A. P. (2009). Inventário de Habilidades Sociais para adolescentes - IHSADEL-PRETTE: Manual de aplicação, apuração $e$ interpretação [Social Skills Inventory for Adolescent SSIA-DEL-PRETTE: Application manual, calculation and interpretation]. São Paulo, SP: Casa do Psicólogo.

Del Prette, Z. A. P., \& Del Prette, A. (2010). Habilidades sociais e análise do comportamento: Proximidade histórica e atualidades [Social skills and behavior analysis: Historical connection and new issues]. Perspectivas, 1(2), 104-115. Retrieved from http://pepsic.bvsalud.org/scielo.php?script=sci_ arttext\&pid=S2177-35482010000200004

Del Prette, Z. A. P., Teodoro, M., \& Del Prette, A. (2014). Social skills of adolescents: Convergent validity between IHSA-Del-Prette and Messy. Estudos de Psicologia (Campinas), 31(1), 15-24. doi:10.1590/0103166X2014000100002

Eccles, J. S., \& Roeser, R. W. (2011). Schools as developmental contexts during adolescence. Journal of Research on Adolescence, 21(1), 225-241.doi:10.1111/ j.1532-7795.2010.00725.x

Elias, M. J. (1989). Schools as a source of stress to children: An analysis of causal and ameliorative influences. Journal of School Psychology, 27(4), 393-407. doi:10.1016/00224405(89)90016-2

Erath, S. A., Bub, K. L., \& Tu, K. M. (2016). Responses to peer stress predict academic outcomes across the transition to middle school. Journal of Early Adolescence, 36(1), 5-28. doi:10.1177/0272431614556350

Feitosa, F. B., Del Prette, Z. A. P., \& Del Prette, A. (2012). Social skills and academic achievement: The mediating function of cognitive competence. Temas em Psicologia, 20(1), 61-70. Retrieved from http://pepsic.bvsalud.org/ $\mathrm{pdf} / \mathrm{tp} / \mathrm{v} 20 \mathrm{n} 1 / \mathrm{v} 20 \mathrm{n} 1 \mathrm{a} 06 . \mathrm{pdf}$
Gresham, F. M., Elliot, S. N., \& Kettler, R. J. (2010). Base rates of social skills acquisition/performance deficits, strengths and problems behaviors: And analysis of the social skills improvement system-rating scales. Psychological Assessment, 22(4), 809-815.doi:10.1037/ a0020255

Instituto Nacional de Estudos e Pesquisas Educacionais Anísio Teixeira. (2015). Censo escolar. Brasília, DF: Inep. Retrieved from http://inep.gov.br/censo-escolar

Kim, H. Y., Schwartz, K., Cappella, E., \& Seidman, E. (2014). Navigating middle grades: Role of social contexts in middle grade school climate. American Journal of Community Psychology, 54(1-2), 28-45. doi:10.1007/ s10464-014-9659-x

Konold, T. R., Jamison, K. R., Stanton-Chapman, T. L., \& Rimm-Kaufman, S. E. (2010). Relationships among informant based measures of social skills and student achievement: A longitudinal examination of differential effects by sex. Applied Developmental Science, 14(1), 18-34. doi:10.1080/10888690903510307

Lane, K. L., Oakes, W. P., Carter, E. W., \& Messenger, M. (2015). Examining behavioral risk and academic performance for students transitioning from elementary to middle school. Journal of Positive Behavior Interventions, 17 (1), 39-49. doi:10.1177/1098300714524825

Leme, V. B. R., Del Prette, Z. A. P., \& Coimbra, S. (2015). Social skills, social support and well-being in adolescents of different family configurations. Paidéia (Ribeirão Preto), 25(60), 9-17. doi:10.1590/1982-43272560201503

Leme, V. B. R., \& Marturano, E. M.(2014). Preditores de comportamentos e competência acadêmica de crianças de famílias nucleares, monoparentais e recasadas [Predictors of children's behavior problems and academic competence of nuclear, separated and remarried families]. Psicologia: Reflexão e Crítica, 27(1), 153-162. doi:10.1590/S0102-79722014000100017

Maia, F. A., \& Soares, A. B. (2014). Habilidades sociais na transição do segundo ciclo do ensino fundamental [Social skills in the transition of the second cycle of middle school]. In L. Campos (Org.), Resiliência \& habilidades sociais: Reflexões acerca de suas articulações e seus desdobramentos na escola e na vida [Resilience and social skills: Reflections on your joints and its consequences in school and in life] (pp. 21-40). Curitiba, PR: Appris.

Marturano, E. M. (2008). Tensões cotidianas na transição para a primeira série: Um enfoque de desenvolvimento [Daily hassles during the transition period to the first grade of the primary school: A developmental view]. Psicologia em Estudo, 13(1), 79-87. doi:10.1590/S141373722008000100010 
Marturano, E. M., \& Pizato, E. C. G. (2015). Preditores do desempenho escolar no $5^{\circ}$ ano do ensino fundamental [Predictors of academic achievement in the 5th grade of elementary school]. Psico, 46(1), 16-24. doi:10.15448/1980-8623.2015.1.14850

Marturano, E. M., Trivellato-Ferreira, M. C., \& Gardinal, E. C. (2009). Estresse cotidiano na transição para a $1^{\text {a }}$ série: Percepção dos alunos e associação com desempenho e desajustamento [Daily hassles in the firstgrade transition: Student perception and association with school achievement and adjustment]. Psicologia: Reflexão e Crítica, 22(1), 93-101.doi:10.1590/S010279722009000100013

Moilanen, K. L., Shaw, D. S., \& Maxwell, K. L. (2010). Developmental cascades: Externalizing, internalizing, and academic competence from middle childhood to early adolescence. Development and Psychopathology, 22(3), 635-653. doi:10.1017/S0954579410000337

Rende, R. (1994). The stress of first grade and its relation to behavior problems in school. In J. C. DeFries, R. Plomin, \& D. W. Fulker (Eds.), Nature and nurture during middle childhood (pp. 152-164). Malden, MA: Blackwell.

Romano, E., Babchishin, L., Pagani, L. S., \& Kohen, D. (2010). School readiness and later achievement: Replication and extension using a nationwide Canadian survey. Developmental Psychology, 46(5), 995-1007. doi:10.1037/a0018880

Sebanc, A. M., Guimond, A. B., \& Lutgen, J. (2016). Transactional relationships between Latinos' friendship quality and academic achievement during the transition to middle school. Journal of Early Adolescence, 36(1), 108-138.doi:10.1177/0272431614556347

Shoshani, A., \& Slone, M. (2012). Middle school transition from the strengths perspective: Young adolescents' character strengths, subjective well-being, and school adjustment. Journal Happiness Study, 14(1), 1163-1181. doi:10.1007/s10902-012-9374-y

Stasiak, G. R., \& Weber, L. N. D. (2013). Percepção de estresse pelas crianças do primeiro ano do ensino fundamental [Stress perceived by children from first grade of elementary school]. Impulso, 23(56), 35-45. doi:10.15600/2236-9767/impulso.v23n56p35-45

Symonds, J., \& Hargreaves, L. (2016). Emotional and motivational engagement at school transition:Aqualitative stage-environment fit study. Journal of Early Adolescence, 36(1), 54-85. doi:10.1177/0272431614556348

Trivellato-Ferreira, M. C., \& Marturano, E. M. (2008). Recursos da criança, da família e da escola predizem competência na transição da $1^{\mathrm{a}}$ série. Revista Interamericana de Psicología, 42(3), 549-558. Retrieved from http://pepsic.bvsalud.org/ pdf/rip/v42n3/v42n3a15.pdf
Neidiany Vieira Jovarini is a undergraduate student at the Universidade Salgado de Oliveira, Brazil.

Vanessa Barbosa Romera Leme is a Professor at the Universidade do Estado do Rio de Janeiro, Brazil.

Marta Regina Gonçalves Correia-Zanini is a Professor at the Centro Universitário das Faculdades Associadas de Ensino, Brazil.

Received: Aug. 24, 2016

1st Revision: Dec.19, 2016

2nd Revision: Apr. 07, 2017

3rd Revision: Nov. 15, 2017

Approved: Feb. 08, 2018

How to cite this article:

Jovarini, N. V., Leme, V. B. R., \& Correia-Zanini, M. R. G. (2018). Influence of social skills and stressors on academic achievement in the sixth-grade. Paidéia (Ribeirão Preto), 28, e2819. doi:http://dx.doi.org/10.1590/1982-4327e2819 